\title{
AT THE PRESIDENT'S SIDE: THE ROLE OF THE WHITE HOUSE COUNSEL IN CONSTITUTIONAL POLICY
}

\author{
JEREMY RABKIN* \\ I

\section{INTRODUCTION}

Whatever else it achieved in its first months in office, the Clinton Administration made U.S. citizens more aware of the White House Counsel's Office. The Counsel's Office was at the center of the brief uproar that arose when the press discovered that presidential aides had manipulated the FBI to put White House patronage maneuvers (replacing career officials in the White House travel office with friends or relatives of President Clinton) in a better light. ${ }^{1}$ The apparent suicide of the Deputy Counsel, Vincent Foster, amidst mysterious circumstances, focused new attention on the Counsel's Office, all the more so as the Counsel's Office was accused of mismanaging and manipulating the investigation of Foster's death in peculiar ways. ${ }^{2}$ Counsel Bernard Nussbaum ultimately achieved the distinction of being the first White House Counsel whose activities were visible enough - and controversial enough - for respectable editorialists to condemn his personal performance and demand his removal from the office. ${ }^{3}$

If the Counsel's Office achieved more notoriety in the Clinton Administration, its operations did not become easier to follow. But the role of the Counsel has never been easy to define or to assess. The White House Counsel is often described as "the President's lawyer." By constitutional tradition and statutory provision, however, the president already has an official lawyer: the Attorney General of the United States. The Attorney General has had a place in the president's Cabinet-and an official role in providing legal advice to executive officials-from the time of President Washington. The Counsel is an innovation of recent decades. The Attorney General (along with other top officers in the Justice Department) must be confirmed by the Senate and remain available for frequent congressional appearances, while the Counsel and his aides are

Copyright $\odot 1993$ by Law and Contemporary Problems

* Associate Professor of Government, Cornell University.

For comments on earlier drafts and/or on material contained here, I would particularly like to thank Nelson Lund, Lee Liberman, Charles Fried, John O. McGinnis, Douglas Cox, Steven Calabresi, and Terrence Pell. at A18.

1. Thomas Friedman, White House Asked Aid of F.B.I. in Dismissals, N.Y. TIMEs, Aug. 25, 1993,

2. William Safire, When An Aide Dies Violently, N.Y. TIMES, May 25, 1993, at A15; William Safire, The 28th Piece, N.Y. Times, Aug 12, 1993, at A25.

3. Editorial Desk, The Clues Left by Vincent Foster, N.Y. Times, Aug. 12, 1993, at A24. 
appointed at the sole discretion of the president and (protected by claims of executive privilege) are never called to account by congressional committees. The Attorney General has an array of formal duties and responsibilities, assigned by statute and reflected in a continual flow of rulings, briefs, and other public documents bearing the Attorney General's name or that of accountable subordinates. The White House Counsel has no statutory duties-no statute even acknowledges the existence of the Office-and the Counsel produces almost no public documents under his own name. Whereas the Attorney General can draw on the accumulated expertise and the vast resources of the Department of Justice, the Wnite House Counsel has barely a dozen aides in the White House.

The White House Counsel is, in effect, a rival source of legal advice for the president, but one who necessarily operates in the shadows. The only real advantage of the Counsel, compared with the Attorney General, is that the Counsel is closer to the president-more fully dependent on the president's favor, so situated that he can devote himself more single-mindedly to the president's concerns, literally an "in-house counsel" in the same White House office complex. No president will want to dramatize the fact that he relies more on his in-house counsel than on the far more publicly accountable and better equipped officers of the Justice Department. The Counsel's Office leaves very few finger prints on presidential decisions. The Counsel's Office not only produces very few public records but regards all its communications with the president as shielded by attorney-client privilege and by a perhaps more encompassing executive privilege. So precise details of the Counsel's actions or advice are scarce. ${ }^{4}$ The unofficial character of the office, moreover, allows each president to adjust the role of the Counsel, like that of other White House staff functions, to his own individual preferences and requirements. And the role clearly does vary from one administration to the next. Whereas Clinton Counsel Nussbaum reports seeing the president several times a day, ${ }^{5}$ his predecessor, Bush Counsel C. Boyden Gray, claims rarely to have seen President Bush more than once a week. ${ }^{6}$

At least a few things are clear about the Counsel's Office, however. First, despite its lack of direct statutory grounding, the Counsel's Office has become securely institutionalized in the structure of the White House. Institutional forces, which are grounded in statutory imperatives, guarantee that modern presidents will need access to an immediate staff of legal advisers in the White House. Second, with this staff in place, whatever its routine duties, it is also

4. Scholars searching through presidential libraries have occasionally uncovered suggestive memoranda giving some sense of the Counsel's role in particular disputes. But even this sort of detailed research can reach only part of the story, since much business is now conducted by telephone-in part for the very purpose of avoiding a permanent record of the deliberations involved.

5. David Margolick, An All-Star New York Lawyer Disputes the Idea He's Become a White House Bumbler, N.Y. TiMES, June 11, 1993, at A26.

6. Interview with C. Boyden Gray (May 12,1993). Gray, currently a law partner in Washington at the same firm as former White House Counsel Lloyd Cutler, reports that Cutler claims to have been "in and out of the Oval Office every day" when serving President Carter. 
available to help the president stay abreast of constitutional issues of particular concern to him. Third, by freeing the president from total dependence on the Attorney General and the Justice Department, the Counsel's Office can help presidents to resist the inertial tendencies of the Justice Department-or to counteract the political and institutional pressures that are most powerful in the Justice Department. Put more succinctly, the existence of the White House Counsel allows the president to play a more independent role in constitutional disputes. In ways that may never be fully known, that is sure to be important.

\section{II}

\section{ORIGINS AND GROWTH OF THE COUNSEL'S OFFICE}

At first glance, there was nothing inevitable about the development of the Counsel's Office. For most of U.S. history, presidents did not have a separate legal counsel in the White House. The Canadian Prime Minister, who has developed a large staff comparable in many ways to the White House staff, still does not have a counterpart to the Counsel. ${ }^{7}$ Nor was the development of the Counsel's Office an immediate outgrowth of the "modern presidency."

Most scholarship on the presidency traces the origins of the White House staff to the Reorganization Act of $1939 .{ }^{8}$ That measure in turn is usually regarded as the ultimate legislative response to the Report of the Committee on Administrative Management (the so-called Brownlow Report) with its famous admonition, "The President needs help." Neither the Reorganization Act nor the Brownlow Report-for all their emphasis on the president's need for staff assistance in the White House-made any mention of a need for a separate legal adviser in the White House. And the initial White House staff, assembled under the authority of the Reorganization Act, did not, in fact, include a legal officer. $^{10}$

The Counsel's Office arose out of personal, rather than institutional, needs. The first person to be designated as a legal adviser on the White House staff was Judge Samuel Rosenman of New York. Rosenman had been a close personal adviser during Franklin Roosevelt's term as Governor of New York, a status acknowledged in Albany with the title of "Counsel to the Governor." Appointed by Roosevelt to New York's highest court in 1932, Rosenman

7. In 1990, the Canadian Prime Minister had a staff of 107 assistants. James Simeon, Prime Minister's Office and White House Office: Political Administration in Canada and the United States, 21 PRESIDENTIAL STUDIES Q. 559, 568 (1991).

8. Ch. 36, 53 Stat. 561 (1939). Section 301 authorizes the presidential appointment of "not to exceed six administrative assistants."

9. President's Committee on Administrative Management, Report with Special STUDIES 6 (1937). A fiftieth anniversary retrospective on the Brownlow Report used this line as its summary title: FREDERICK MOSHER, THE PRESIDENT NEEDS HELP (1988).

10. In the U.S. Government Organization Manual for 1940, three people are described as "secretary to the President" and another three as "Administrative Assistant," but beyond these only a "personal secretary" and an "executive clerk" are mentioned in the listing of the "White House staff." See U.S. GOVERNMENT ORGANIZATION MANUAL (1940). 
continued to offer informal advice to FDR and was finally persuaded to resign from the bench and take up a full-time, official position at the White House in 1941. ${ }^{11}$

In Washington, Rosenman was given the title of "Special Counsel to the President," which seemed to imply something provisional, anomalous, or tentative about the Counsel's status. Clark Clifford, who was trained by Rosenman to succeed him as "Special Counsel," claims that President Roosevelt actually had intended to offer Rosenman the more confident or general title of "Counsel to the President." But "at the last minute," according to Clifford, Attorney General Francis Biddle successfully prevailed on Roosevelt to abandon that "simple and elegant title ... . on the grounds that such a title would undercut the role of the Attorney General as the President's chief legal adviser."12

In fact, Rosenman was much more than a legal adviser, which meant that in practice he was much less than a formal counselor on issues of law. Rosenman had no staff of his own and was not equipped to undertake extensive legal research. He spent most of his time working on public statements for the President-messages to Congress and political speeches. He did not vet them for legal problems: he was himself the principal speech writer. In a very small White House staff, he seems to have done a bit of everything. According to Clifford, Rosenman's activities were so various and his methods so informal, that no one thought it odd when Rosenman recruited Clifford, then a young naval aide (still in uniform), to assist him with his work. ${ }^{13}$

Rosenman set the pattern for the next quarter-century. Clark Clifford was involved in a vast range of political issues in the Truman White House, with little pretense that his contributions in most instances were specifically "legal."14 Like Rosenman, Clifford was one of a small circle of close advisers, whose

11. For an overview of Rosenman's career, see SAMUEL B. HAND, COUNSEl AND ADVICE: A Political BIography of Samuel I. Rosenman (1979).

12. See Clark Clifford \& Richard Holbrooke, Counsel to the President, A Memoir 54 (1991). Clifford presumably heard the story directly from Rosenman. It is told with more piquant detail in Daniel Meador, The President, The ATtorney General and the Department OF JUSTICE 130 (1980), which reports that Attorney General Biddle told Roosevelt that "under the Constitution" the authority to advise the president on legal affairs had to be vested in the Attorney General and FDR then made a point of not announcing Rosenman's appointment until Biddle had left for a trip to Mexico.

13. "Rosenman worked without any aides, simply reaching out to anyone he thought could be of help .... [S]o informal and small was the White House in those days that neither of us saw anything odd in the fact that upon leaving [Washington to assist President Truman at the Potsdam Conference in Germany], the President's Special Counsel left a temporary Assistant Naval Aide with responsibility for continuing research and drafting of a message on Universal Military Training . ..." CLIFFORD \& HOLBROOKE, supra note 12, at 55-56.

14. "To the inevitable question What did a Special Counsel do?, the simplest and most accurate answer was: Whatever the President wanted. The title of Special Counsel was grant [sic], but the job had no power or authority other than that conferred by the President ... . [M]y value was as an adviser or counselor, and not as an administrator or bureaucrat." Id. at 75. It is revealing that George Elsey, who was officially Clifford's "sole assistant" in the White House, id. at 6, a person Clifford describes as "my closest associate and collaborator," $i d$. at 51 , and the person Clifford therefore "would very much like to have recommended" to succeed him as Special Counsel was not a lawyer at all: this was, however, regarded as disqualification for service as "Special Counsel," id. at 259. 
responsibilities also happened to include a few special legal chores. Clifford was involved in everything from campaign strategy in the 1948 election to disputes with the State Department about U.S. policy toward the emergence of a Jewish state in the Mideast. ${ }^{15}$

Throughout the 1960s, memoirs suggest a similar degree of informality and open-ended activity for the White House staffer designated as "special counsel." Theodore Sorensen, who served President Kennedy with this title, had been Kennedy's principal aide during Kennedy's service in the Senate. In the White House, Sorensen continued to act as principal speech writer and close adviser on a broad range of matters, including responses to the Cuban Missile crisis. ${ }^{16}$ Harry McPherson, who held the title of "special counsel" under President Lyndon Johnson, developed a comparably broad array of White House responsibilities, becoming actively involved, for example, in White House deliberations about the bombing of North Vietnam. ${ }^{17}$ Both Sorensen and McPherson were subsequently invited to appear at a conference of presidential "chiefs of staff." No one held that title in the Kennedy and Johnson Administrations, but these "special counsels" were as close to that general, coordinating role as any presidential aides in their periods of service in the White House. ${ }^{18}$

The great variation in titles illustrates the improvised nature of the Counsel's role during the 1960s. Lyndon Johnson actually bestowed the "simple elegant title" of "Counsel to the President" on Myer Feldman, who, as Sorenson's assistant in the Kennedy White House, had carried the title of "Deputy Special Counsel." A year later, another of Sorensen's assistants replaced Feldman but under the old title of "Special Counsel," which remained Harry McPherson's title

15. Clifford's participation in White House deliberations on Palestine provoked resistance and resentment from the Secretary of State. Clifford's role was resented, however, not for intruding "legal" issues into foreign policy, but-revealingly-because he was regarded as introducing "political" considerations into this field. Secretary of State Marshall protested to President Truman, "I fear that the only reason Clifford is here [in a meeting with the President to discuss the issue] is that he is pressing a political consideration with regard to this issue. I don't think politics should play any part in this." Id. at 12 .

16. For example, Arthur Schlesinger's memoir of the Kennedy Administration offers nearly a page for each day to describe the inner history of the Kennedy White House: Sorensen is one of the central figures in the tale, but is never described offering legal advice. ARTHUR SCHLESINGER, A THOUSAND DAYS, JOHN F. KENNEDY IN THE WHITE HOUSE 960 (1965).

17. Lyndon Johnson mentions McPherson's involvement in deliberations on the proposed halt to bombing in Vietnam in order to encourage North Vietnam to negotiate peace. LYNDON B. JOHNSON, The Vantage Point, Perspectives of THE PREsidency 410, 418-19, 540 (1971). Johnson refers to McPherson simply as "one of my assistants," id. at 410, without acknowledging any particular functions as legal counsel. McPherson's own memoir devotes some 200 pages to his service in the White House, HARRY MCPHERSON, A POLITICAL EDUCATION 245-455 (1972), but only a dozen pages (273-85) to matters specifically pertaining to his role as "counsel" (and almost all of that discussion focuses on responses to legislation). Starting with legal duties as an "understudy" to Special Counsel Lee White, McPherson reports that "[m]onths passed before [he] felt fully employed at the White House." Id. at 250.

18. The conference is summarized in Samuel Kernell, The Creed and Reality of Modern White House Management, in CHIEF OF STAFF: TWENTY-FIVE YEARS OF MANAGING THE PRESIDENCY 193-222 (Samuel Kernell \& Samuel Popkin eds., 1986). 
over the next three years. ${ }^{19}$ The Nixon White House similarly began by conferring the title "Counsel to the President" on top aide John Ehrlichman, then retired the title again and gave the title of "Special Counsel" to three separate political advisers simultaneously. ${ }^{20}$

The modern form of the Counsel's Office-and certainly the modern nomenclature-seems to have settled into place with the appointment of John Dean as "Counsel to the President" in 1971. Dean, whose title has been continued ever since, was the first "Counsel" (or "Special Counsel" for that matter) who was appointed without any previous personal connection to the President. By Dean's account, he began his service as Counsel as a marginal figure with no assistants. He saw the President no more than once every few weeks and then mostly in connection with ceremonial occasions. ${ }^{21}$ Dean was the first "Counsel" (or "Special Counsel") whose duties were primarily a matter of lawyering. He was also the first counsel to seek out new responsibilities in a specifically legal vein-because he did not have much else to do. And his efforts at "empire building" succeeded. Dean began the process of expanding the specifically legal capacities of the Office of Counsel, so that the phrase came to be associated not with the honorific title of one adviser but with an entire separate bureaucracy. Dean soon secured a full-time assistant, then hired two additional lawyers and a full-time detective for the Counsel's Office. ${ }^{22}$

Not all of John Dean's successors, to be sure, have started out as marginal figures. Dean's sensational role, first in the coverup of the Watergate scandals, then in their exposure to Congress and to independent prosecutors, seems to have provided a lesson for later presidents. Since then presidents have sought better known or more trusted figures. The Counsel's precise role has varied from one administration to the next, however, depending on the degree of

19. See the entries for "The White House" in U.S. GovernMENT ORGANIZATION MANUAL, 1963-1964, 1964-1965 and following years. McPherson's memoir, supra note 17, speaks of Meyer Feldman and Lee White (who succeeded Feldman) as his own predecessors, without making anything of the change in titles: "Mike Feldman, one of the last of the Kennedy staff, would soon be leaving. His successor as special counsel [sic] was to be Lee White. The President wanted to know if I would like to understudy Lee, who would be moving on himself." MCPHERSON, supra note 17, at 235. And again: "The President needed a Special Counsel. Clark Clifford ... had held the job in Truman's day, Sorensen and Mike Feldman in Kennedy's, Lee White and then I in Johnson's." Id. at 273.

20. Conferring the same title on three separate individuals suggests by itself that the title was something of an honorific. In fact, the three advisers (Murray Chotiner, Charles Colson, and Harry Dent) were preoccupied with party politics and not involved in legal or policy issues. Colson and Dent continued to maintain the title of "Special Counsel" without in any way reporting to "Counsel" John Dean or assisting Dean in his own work.

21. JOHN DEAN, BLIND AMBITION 5, 10 (1976). In fact, Dean reports that he had met neither the President nor the President's Chief of Staff (Haldeman) before being selected for the Counsel's job on the recommendation of Attorney General Mitchell. Id. By contrast, when Nixon wanted to reconsider his administration's policy toward school desegregation-which required a careful consideration of how much leeway statutes and court decisions on the issue actually left to the Justice Department and the Department of Health, Education and Welfare-he turned not to Dean but to White House Counselor Leonard Garment, who was, to be sure, an attorney, but had no precise law-related duties in the White House. This episode is described in instructive detail in BRADLEY PATTERSON, JR., THE RING OF POWER, THE WhITE House STAFF AND ITS EXPANDING ROLE IN GOVERNMENT 40-43 (1988).

22. DEAN, supra note 21 , at $28,30$. 
intimacy and trust between Counsel and president. President Ford chose as Counsel one of his oldest friends and professional associates, Phillip Buchen, a figure who seems to have been important in a close-knit White House. ${ }^{23}$ President Carter followed a similar initial impulse in appointing his campaign counsel and fellow Georgian, Robert Lipshutz, to be his White House Counsel; but Lipshutz, lacking previous Washington experience, apparently played a peripheral role in actual White House policy deliberations. ${ }^{24}$ When Carter replaced Lipshutz with Lloyd Cutler, a very prominent and highly experienced Washington lawyer, the change implied a readiness to see the Counsel assume a much larger role. ${ }^{25}$ Cutler certainly took his appointment in this spirit and quickly involved himself in an extraordinary range of administration affairs, sitting in on National Security Council meetings, taking part in delicate missions involving the Shah of Iran and the selling of the Strategic Arms Treaty to the Soviet Union. ${ }^{26}$

None of the attorneys who served Ronald Reagan as Counsel brought as much stature to the post or achieved so much prominence in it. Fred Fielding, Counsel in Reagan's first term, had learned the job in serving as assistant to John Dean in the Nixon Administration. He remained distinctly subordinate to James Baker, the White House Chief of Staff in Reagan's first administration. ${ }^{27}$ When Treasury Secretary Donald Regan became White House Chief of Staff at the outset of Reagan's second term, Regan brought along to the White House one

23. See Gerald Ford, A TIMe to Heal (1979), in which Ford relates the long personal association between Ford and Buchen. Ford and Buchen had been fraternity brothers in college and when they finished legal training, the two went into private practice together as "Ford and Buchen." Id at 57. It was Buchen who urged Ford to make his first run for Congress in 1948, id. at 64, Buchen who coached Ford for his confirmation proceedings as Vice-President, id. at 109, and Buchen who took the initiative in organizing a transition staff when it began to appear that President Nixon would have to resign his office to then Vice-President Ford, id. at 23-24. The two were so close that Ford discussed his initial run for Congress with Buchen before even discussing it with his wife, id. at 64 , and Buchen took the initiative in planning for Ford's transition to the presidency without notifying President Nixon or Ford, himself, id. at 24.

24. See Colin Campbell, Managing the Presidency, Carter, Reagan and the SEARCH For EXECUTIVE HARMONY 88 (1986) ("Lipshutz failed to become a major official in the administration."). Carter's Attorney General, Griffin Bell, described Lipshutz as a "relatively unassertive, retiring lawyer" and "not a combative, overly assertive individual." GRIFFIN BELL \& RONALD J. OSTROW, TAKING CARE OF THE LAW 37, 40 (1982).

25. CAMPBELL, supra note 24 , at 88 , connects the Cutler appointment with a larger effort in the summer of 1979 "to add prestige to a flagging White House."

26. Jimmy CARTER, KeEPING FAITH, MEMOIRS OF A PResident 5-8 (1982) (Cutler's involvement with negotiations on Iranian hostage crisis); id. at 518 (military rescue mission to Iran); id. at 468-69 (moving the Shah of Iran to new refuges); id. at 526 (boycott of Moscow Olympics). Cutler himself alludes to the wide range of his activities in Lloyd Cutler, The Role of the Counsel to the President of the United States, 35 RECORD, BAR Ass'N CITY OF N.Y. 470 (1980).

27. This was not simply a reflection of Baker's formal status at Chief of Staff. Reagan, though more willing to delegate details to subordinates than most modern presidents, did not in his first term allow everything to be channeled through a single staff director. In Reagan's first term, presidential counselors Edwin Meese and Michael Deaver were regarded as constituting, with Baker, a "triumvirate" of equals within the White House, which was transformed into the "Big Four" with the addition of Judge William Clark as National Security Advisor after 1982. Fielding was an aide to Baker (occasionally assisting Meese), but never a contender for a place in the top circle of aides. CAMPBELL, supra note 24, at 94 . 
of his top aides, Peter Wallison, to serve as counsel. ${ }^{28}$ Barely a year later, amidst recriminations over the emerging Iran-Contra scandal, Regan was replaced as Chief of Staff by former senator Howard Baker. Baker replaced Wallison with one of his own close associates, A.B. Culvahouse. Culvahouse, who had served as legislative aid to Baker in the Senate and on Baker's retirement from the Senate, had moved with him to a Washington law firm. But in an Administration that had already lost most of its policy momentum and was preoccupied with the destabilizing effects of scandal, Culvahouse was not associated with major policy initiatives. ${ }^{29}$ Gray's family background was similar to Bush's and the families were socially connected in the $1950 \mathrm{~s}^{30}$ More importantly, in the Reagan years, Gray had served for eight years as Counsel to Vice-President Bush and the two had developed an unusually close and trusting professional relationship in that period. Gray thus took a prominent role in Bush Administration deliberations over the shape of new Clean Air Act amendments, over the Americans with Disabilities Act, and the 1991 Civil Rights Act. $^{31}$

Even prominent Counsels like Lloyd Cutler or Boyden Gray did not achieve the dominant staff position of Clark Clifford or Theodore Sorenson, however. Carter's Chief of Staff, Hamilton Jordan, who had masterminded Carter's election in 1976, remained the President's most trusted aide; Cutler was an outsider "with special experience," as Carter put it. ${ }^{32}$ Boyden Gray, for all his close ties to President Bush, was publicly scolded by Bush Chief of Staff John Sununu when Gray protested the legal form of a major "deal" between the Bush Administration and congressional leaders on aid to the Nicaraguan contras. ${ }^{33}$ Subsequently, Gray's effort to draft an executive order to federal agencies on proper compliance with the new Civil Rights Act was abruptly repudiated by the White House. ${ }^{34}$ With all his extra ventures, Gray was, like his immediate predecessors, the Counsel, not the Chief of Staff or the chief domestic policy adviser. Gray, himself, explained to journalists that it was not his place as Counsel to handle political issues, but simply to handle background legal issues. $^{35}$

28. Eric Effron, Culvahouse Assumes Key White House Legal Post, LEgal Times, Mar. 9, 1987, p. 1, offers a brief sketch of Wallison's service, on the occasion of his departure.

29. Vicki Quade, The President Is His Only Client, 15 THE BARRISTER, Winter/Spring 1988, at 5-6 (interview with A.B. Culvahouse, Jr., 1988).

30. As a Washington columnist summed it up, “Bush's father played golf with Gray's father." Mary McGrory, Gray's Finger Pointing Counsel, WASH. POST, Mar. 28, 1989, at A2.

31. For an overview of Gray's work with Bush during the Reagan Administration, see Philip Combs, The Distant Drum of C. Boyden Gray, WASH. PoST, Mar. 31, 1989, at D1.

32. CARTER, supra note 26, at 61 .

33. David Hoffman, Sununu Rebukes Counsel, Chief of Staff Angry at Gray's Challenge to Contra Aid Deal, WASH. POST, Mar. 28, 1989, at A1.

34. Andrew Rosenthal, President Tries to Quell Furor on Interpreting Scope of New Law, N.Y. TIMES, Nov. 22, 1991, at A1.

35. As Counsel, Gray was responsible for reviewing FBI background reports and other documents pertaining to presidential nominations. Thus, when John Tower, President Bush's initial nominee for Secretary of Defense, was rejected by the Senate amidst reports of his record of heavy drinking and 
Compared with the status of the position before the Nixon years, the Counsel's Office-whatever the profile of the individual Counsel-was a more secure base. Although men such as Clifford or Sorensen may have acquired several specialized duties with the title "Special Counsel," they did not acquire and do not seem to have needed a separate legal staff. Recent Counsels, whether they played a larger role or not, have had their own staff and their own institutional niche.

The Counsel's Office has grown steadily. In 1980, Lloyd Cutler recruited a staff of six lawyers to assist him. ${ }^{36}$ By 1986, Fred Fielding reported a staff of eight to ten lawyers. ${ }^{37}$ By 1987 , the number had grown to fourteen lawyers and stayed in that range during the Bush Administration. ${ }^{38}$ The Clinton White House started out with a staff of thirteen lawyers-and had appointed a Deputy Counsel and a brace of "Associate Counsels" and "Assistant Counsels" weeks before any formal nominations to the Justice Department. ${ }^{39}$ So well-developed and extensive are the distinctive legal duties of the Counsel, they can no longer be tacked onto the responsibilities of the chief of staff or a principal domestic policy adviser. The Counsel's Office is now preeminently an office of lawyers, doing lawyers' work.

Why does the contemporary White House need to have its own special legal staff? Why have successive administrations found it necessary to maintain and expand this staff over the past two decades? Several factors seem to be important. Each relates to a larger dimension of the pressures on the contemporary presidency.

\footnotetext{
"womanizing," there were complaints that Gray had "focused too narrowly on whether Tower was guilty of serious wrong-doing rather than considering whether Senate Democrats could mount a political offensive." Defending his performance, Gray explained, "I wasn't the political manager! . . . My role was not to make political judgments about it. I had nothing to do with the selection of Tower to begin with." Combs, supra note 31 , at D8.

36. Cutler, supra note 26 , at $470-80$.

37. David O. Stewart, The President's Lawyer, A.B.A. J. Apr. 1, 1986 at 59.

38. Quade, supra note 29, at 6.

39. The "Federal Yellow Book" for Winter 1993 (dated January 20, 1993), lists a Counsel, Deputy Counsel and two Associate Counsels. White House aides confirmed that the total number of lawyers working in the Counsel's Office was 13 by early February. (Official listings of the White House staff never give the full number of lawyers because extra lawyers are usually "detailed" from departments to circumvent congressional restrictions or concerns about excessive size of the fulltime staff.) Walter Dellinger, then serving in the Counsel's Office, suggested in a telephone interview that positions in the Counsel's Office were more easily filled than those in the Justice Department because the latter require Senate confirmation and it would be imprudent to advance any other Justice Department nominations before an Attorney General had been confirmed, lest this complicate the AG's own confirmation. It is still notable that Clinton's Counsel, Bernard Nussbaum, was described in the official staff listing not only as "Counsel" but also as "Assistant to the President"- an additional honorific not even given to Boyden Gray.
} 
III

\section{THE FORCE OF ETHICS}

Issues dealing with "ethics" have been central to the expansion of the White House Counsel's Office. In 1970, John Dean's effort to expand his power base in the Nixon White House focused on providing advice about conflicts of interest. Dean's memoir of his White House service describes his strategy for building up the Counsel's Office in these terms:

Our conflict of interest duties were the key .... The work was complicated and boring, but I had already sensed that it would produce new business. If we were alert in conflict-of-interest reviews and investigations, we would have a small say in Presidential appointments. As with any law firm, our influence depended largely on our reputation and our reputation was good. We cultivated it with care. $^{40}$

As it turned out, Dean was in a growth "business." The first treatise-length study of federal conflict of interest requirements had been published only a few years before. ${ }^{41}$ President Johnson had then issued to executive personnel the first systematic executive order on rules for avoiding conflicts of interest. ${ }^{42}$ There were continuing questions, often raised by lawyers in other parts of the government. ${ }^{43}$ The Counsel's advice could sometimes be disregarded and many legal improprieties-and some outright crimes-were apparently undertaken without consulting the Counsel. Still, requests for legal advice multiplied, and within a year the three lawyers on Dean's staff "were hopelessly overworked." 44

The Nixon White House could still twitch at the recollection of black-eyes sustained by earlier administrations over petty corruption scandals. Subsequent administrations must have trembled when recollecting that the Watergate scandal had ultimately devoured the entire Nixon Administration. President Ford faced an embarrassing (and agonizingly slow) independent counsel investigation of his own past actions, during his 1976 reelection campaign. ${ }^{45}$ The Carter Adminis-

40. DEAN, supra note 21 , at 29.

41. NEW YORK CITY BAR ASSOCIATION CONFLICT OF INTEREST AND FEDERAL SERVICE (Special Committee on Federal Conflict of Interest, 1960); BAYLESS MANNING, FEDERAL CONFLICT OF INTEREST (1961).

42. Executive Order 11222 (1965), 3 C.F.R. 306 (1964-65), reprinted in 18 U.S.C. 201 (1988).

43. Dean describes, for example, the case of a White House staff mission to Vietnam that returned with Chinese rifles as souvenirs. Treasury Department officials sought to classify the rifles as "illegally imported," and Dean then managed to save these souvenir rifles by discovering an obscure statutory basis to classify them as legal "war trophies." DEAN, supra note 21, at 29.

44. Id.

45. The investigation focused on Ford's conduct as House Minority Leader, some years earlier, when he was suspected of having improperly received gifts from labor leaders to influence his vote. Though eventually cleared of all allegations, Ford was embarrassed to have the investigation drag on until the eve of the 1976 election. Ford was particularly exasperated that the Special Prosecutor in charge of the investigation was only serving part-time in the position, while continuing to teach at Georgetown Law Center and thus had "neither the time nor the staff to expedite the probe." But Ford felt he could not raise the matter with Attorney General Levi, "because I had given him my word that I would never interfere with an investigation. Nor could I challenge the Special Prosecutor because that would smack of Nixon and the Saturday Night Massacre all over again." FoRD, supra note 23, at 418. 
tration, which came into office pledging to restore trust and integrity, quickly found itself battered by the demands of "post-Watergate morality." Highly publicized scandals forced the early departure of Carter's Director of the Office of Management and Budget and his top adviser on drug policy and nearly forced the resignation of the White House Chief of Staff. In the early months of the Reagan Administration, National Security Adviser Richard Allen was forced to resign over charges that he had failed to report a gift given by a foreign journalist to Mrs. Reagan. None of these incidents ended with criminal convictions or even with clear evidence of wrong-doing, but they confirmed that "the appearance of impropriety" could readily touch off a torrent of bad publicity in a press that had become especially alert to "scandal" after Watergate.

Washington's preoccupation with scandal was powerfully reinforced by changes in law, which had a direct and powerful effect on the demand for the services begun by John Dean's White House "law firm." The Ethics in Government Act, enacted in $1978,{ }^{46}$ institutionalized a climate of public suspicion, and consequent executive defensiveness, in two ways. First, it laid down elaborate and very demanding public disclosure requirements for the financial assets and income sources of government officials. Second, it provided for the routine appointment of a "special prosecutor" (subsequently redesignated an "independent counsel") to investigate and prosecute executive officials suspected of criminal activity.

The heightened disclosure standards were designed to make it much easier for journalists or other investigators to detect possible "conflicts of interest." As the disclosure requirements began to approach the complexity of the tax code, it also became easier for affected officials to make inadvertent mistakes in their disclosure forms-a serious danger in an atmosphere in which the withholding of information could be readily fanned into a "scandal" or perhaps indeed into a criminal offense. This put pressure on the White House Counsel's Office to provide precise guidance on disclosure requirements and to provide close scrutiny of potential nominees for high positions, before congressional committees and the press conducted their own scrutiny. ${ }^{47}$ In the 1980 s, Counsel Fred Fielding assured prospective nominees that the White House Counsel's Office would be on their side in a fight with Congress or the press but blandly conceded that nominees might wish to secure their own lawyers to assist them in the early stages of preparing for confirmation proceedings. ${ }^{48}$

46. The Ethics Act is codified at 28 U.S.C. $\$ \S 591-599$ (1988). For brief descriptions of the scandals cited above, see SuZANNE GaRMENT, SCANDAL, THE CRISIS OF MISTRUST IN AMERICAN POLITICS 4347 (1991) (OMB Director Bert Lance); id. at 51 (Drug Adviser Peter Bourne); id. at $51-54$ (Chief of Staff Hamilton Jordan); id. at 59-64 (National Security Adviser Richard Allen).

47. Stewart quotes Fred Fielding's estimate that his office had screened more than 4800 appointees over the previous five years "for conflict of interest and other problems." Stewart, supra note 37.

48. Fred Fielding, Presidential Appointments, DIRECTORS \& BOARDS, Spring 1983, at 13:

As a practical matter, the candidate with a complicated financial picture or controversial appointment must remember that the first obligation of the Counsel to the President's Office is to its client, the President. Ordinarily, ... our goals and the candidate's are mutual; but the 
The specter of the independent counsel put still more pressure on the Counsel's Office, since it meant that those already in office had to be much more alert to possible legal infractions. The Ethics Law requires the appointment of an independent counsel whenever there is some evidence of wrongdoing. The independent counsel then has no effective hierarchical supervision or constraining accountability. The independent counsel is literally on his own with no competing cases or assignments to distract from the "case" assigned. And where ordinary prosecutors usually do not announce the targets of their investigations until ready to seek an indictment, the mere appointment of an independent counsel immediately generates public attention and the blackening of reputations, even when no indictment ultimately ensues. ${ }^{49}$ Far from slackening with time, new legislation at the outset of the Bush Administration strengthened disclosure and conflict of interest requirements in response to perceived laxness on these matters in the Reagan Administration. ${ }^{50}$ In these circumstances, the advice of the White House Counsel has taken on much greater importance.

The White House Counsel is by no means the only source for advice about steering clear of legal or ethical violations. There is a separate Office of Government Ethics for the executive branch and, in addition, every agency and department has its own general counsel and legal staffs. Even within the Executive Office of the President, general counsels and legal staffs have proliferated in the past two decades. Just as the White House has its own legal counsel, separate "counsels" were also installed to advise the Office of Management and Budget, the Council on Environmental Quality, the Office of the U.S. Trade Representative, the Council on Wage and Price Stability, the National Security Council, the Office of White House Administration, the Office of National Drug Control Policy Coordination, and even the Office of the Vice President-all within the White House or the Executive Office of the President. $^{\text {st }}$

candidate facing difficult financial and other decisions may find it worthwhile-and comforting-to have his own counsel in all deliberations.

49. For politically sophisticated accounts of how the system actually operates, see Terry Eastland, The Independent Counsel Regime, PUBliC INTEREST, No. 100, Summer 1990, at 68-80; see also GARMENT, supra note 46 , at 83-108.

50. New ethics legislation in $\mathbf{1 9 8 9}$ further tightened disclosure requirements and put more severe limits on post-employment lobbying or consulting by former government officials.

51. The units within the Executive Office of the President (which was first established in 1939) have varied considerably over the past fifty years. The Council on Wage and Price Stability, for example, was created by the Ford Administration, then abolished by the Reagan Administration. Many units have been renamed and reshuffled over the years, making it difficult to make clear comparisons from one decade to the next. But it is clear from successive editions of the U.S. Government Organization Manual that the trend has been toward the proliferation of separate "counsels." In 1957, for example, only the president and the "Office of Defense Mobilization" within the EOP had their own designated "counsels," while even the Bureau of the Budget did not have a designated counsel. By 1961, the Bureau of the Budget had its own "general counsel." By 1976, there were six units in the EOP with their own "general counsel" in addition to the president's own "Counsel." 
The White House Counsel's Office cannot remain aloof, however, so long as scandal will rub off on the White House itself. Accordingly, while prospective presidential appointees are duly screened for conformity with ethics and disclosure laws by the legal staffs of the departments or agencies to which they will appointed, the entire screening process is carefully rechecked by the White House Counsel's Office in a process known to lawyers involved as an "ethics scrub." A nomination that blows up in scandal, or even in petty disputes over what was or was not properly disclosed, will blacken, not the agency involved, but the president who made the nomination. Similarly, when a dispute arises about an official's compliance with ethics requirements, the press looks immediately to the White House for its reaction, and it is the reaction of the White House Counsel that wins attention, much more than that of the lawyers on hand at the agency involved.

A situation of this kind is a delicate matter for the White House Counsel. No lawyer wants to make snap decisions on a "case" before closely studying the facts and carefully reviewing the relevant law. But when the White House is pressed for a response, the president or his top aides turn to the Counsel's Office. Accordingly, the Counsel's Office tries to anticipate trouble by screening prospective nominees and has tried to acquire the staff resources and expertise to deal with trouble when it does arise. For example, when Bob Martinez, President Bush's "Drug Czar," was accused of mishandling campaign funds, it was the White House Counsel who was quoted in the first media story on the legal standards applicable to the incident. ${ }^{52}$

Staff lawyers who served in the Counsel's Office during the Bush years report that the great bulk of staff resources were spent on "ethics" matters. But White House lawyers also expend considerable time and effort handling related legal questions. For example, during the last years of the Reagan Administration, very substantial legal resources in the White House were devoted to screening and cataloguing internal documents to accommodate congressional and independent counsel probes of the Iran Contra scandal. ${ }^{53}$ Even without the pressure of a major scandal, the Counsel's Office plays a central role in deliberations about when executive privilege should be invoked to shield high-level executive communications from disclosure to congressional committees. There are also periodic questions about distinguishing campaign activities from governing activities in the allocation of expenses, questions about which White House records must be preserved under the Federal Records Management Act. ${ }^{54}$ In sum, the full range of "ethics" and "disclosure" requirements has generated a continual demand for legal services in the White House, especially

52. Michael Isikoff, Martinez Used His Drug Policy Office to Route Funds for Bush Campaign, WASH. PoST, Jan. 9, 1992, at A1. Gray's opinion is cited here by Martinez's own counsel, Terrence Pell.

53. Quade, supra note 29 , at 7.

54. Id; See 90 Stat. 2723 (1976). 44 U.S.C.A. $\$ \S 2103,2108,2111$ (West 1991 \& Supp. 1993). 
as changing requirements accumulating over the past fifteen years have opened new sources of doubt and ambiguity for lawyers outside the White House. ${ }^{55}$

This fact goes far in explaining the continual growth of the White House Counsel's Office over the past two decades. Yet, the pressure of ethics requirements is not a complete explanation, since much of the work generated by "ethics" laws can be shared with other agencies, particularly the Justice Department. The question, then, is why the White House has not relied more fully on the Justice Department in dealing with these new pressures, instead of building up its own staff resources. There is a ready answer: the same post-Watergate pressures that generate demands for lawyering on behalf of the White House have, at the same time, significantly complicated and often strained White House relations with the Justice Department. This situation not only makes the White House more eager for in-house legal expertise to cope with "ethics" issues. It also makes the White House more inclined to lean on these same internal lawyering resources in coping with other issues that would previously have been handled almost entirely through the Justice Department.

\section{IV \\ "INDEPENDENT" JUSTICE, VITAL COUNSEL}

The Attorney General is a member of the president's Cabinet, subject to removal at will by the president, just like any other department head. By statute and tradition, however, the Attorney General is responsible for advising all other executive officers, including the president, on the meaning and requirements of existing law. ${ }^{56}$ The Attorney General is also responsible for overseeing the daily operations of the Department of Justice, which is constantly involved in making disputable decisions about whether or not to proceed with particular cases and about what arguments to urge before the courts.

There is, therefore, a built-in tension or ambiguity in the Attorney General's role as chief law officer in the executive branch. Does the Attorney General owe primary loyalty to the president who appoints him-or to the law which she or he interprets and enforces? Put otherwise, should the Attorney General view the president (or the president's administration) as a client and seek, in the manner of a private lawyer, to find plausible legal constructions at every turn to help "the client" to pursue a chosen path? Or should the Attorney General address issues of legal construction in the manner of an idealized judge, seeking the most persuasive reading of the law without regard to the policy consequences?

A recent study of the Attorney General's Office, aptly entitled, Conflicting Loyalties, demonstrates that protests and polemics on behalf of different

55. See, e.g., Exec. Order No. 11,222, 3 C.F.R. 306 (1964-65); Ethics Reform Act of 1989, Pub. L. No. 101-194, 103 Stat. 1716; Resolution to Make Technical Changes in the Ethics Reform Act of 1989, Pub. L. No. 101-280, 104 Stat. 149 (1990) (codified throughout Title 18; see, e.g., 18 U.S.C. $\$ 207$ (Supp. IV 1992)).

56. 28 U.S.C. $\$ \S 511,512(1988)$. 
conceptions of the office have been a recurring feature of federal politics since the early nineteenth century. ${ }^{57}$ Prior to the creation of the Department of Justice in 1870, however, Attorneys General had neither the statutory warrant nor the staff capacity to direct the decisions of the U.S. Attorneys around the country who carried on the bulk of legal work for the federal government. The underlying issue remained rather academic for more than a generation thereafter, given the limited scale of federal responsibilities and the relative weakness and political passivity of presidents in that era. ${ }^{58}$

For most of the twentieth century, presidents seem to have expected their Attorneys General to cooperate with their own political aims. Certainly, most presidents bestowed the position on individuals whose partisan loyalties could be trusted. President Harding appointed his campaign manager to head the Justice Department. Attorney General Daugherty then proceeded to confirm partisan suspicions by becoming entangled in the Teapot Dome Scandal. ${ }^{59}$ Despite this experience, Presidents Eisenhower, Kennedy, and Nixon also appointed their campaign managers to be Attorney General, while Presidents Wilson, Truman, and both Roosevelts all named political party chairmen or active campaigners to the post. ${ }^{60}$ Such appointees may not have converted the Justice Department into compliant tools of presidential whim, but they certainly nurtured close and cooperative relations between the Department of Justice and the White House. As a Justice of the Supreme Court, for example, Robert Jackson dismissed as mere partisan advocacy the advice he had earlier given to Franklin Roosevelt, when serving as his Attorney General. ${ }^{61}$

As late as 1971, Victor Navasky's survey of the Kennedy Justice Department cheerfully described it as "a 32,000 man addition to the White House staff for random presidential business." 62 When Robert Kennedy did allow his scholarly Solicitor General to take positions before the Supreme Court that disappointed civil rights advocates, many of the latter were both baffled and angry, since they assumed that a sympathetic administration could simply force the Justice Department to embrace the positions they favored. Joseph Rauh, a prominent civil rights advocate and past president of the liberal advocacy group Americans for Democratic Action, was particularly emphatic:

57. NANCY BAKER, CONFLICTING LOYALTIES, LAW AND POLITICS IN THE ATtORNEY GENERAL'S OFFICE, 1789-1990, 49-66, 67-77, 126-34 (1992).

58. Cornell Clayton, The Politics of Justice, The attorney General and the Making OF LEGAL POLICY 25-36 (1992).

59. BAKER, supra note 57, notes that Attorney General Daugherty was never directly linked to any role in the Teapot Dome oil lease scandal, but there was so much suspicion around his activities (he was nearly impeached before resigning in 1924) that investigations were set in motion eventuating in his indictment for "conspiracy to defraud the government" on an unrelated matter-on which the charges were finally dropped after two juries reached hung verdicts. Id. at 118-20.

60. Id. at 20-21.

61. "While it is not surprising that counsel should grasp support from such unadjudicated claims of power, a judge cannot accept such self-serving press statements of the attorney for one of the parties as authority for answering a constitutional question, even if the advocate was himself." Youngstown Sheet and Tube Co. v. Sawyer, 343 U.S. 579, at 647 (1952) (Jackson, J., concurring).

62. VICTOR NAVASKY, KENNEDY JUSTICE xiv (1971). 
The independence of the Solicitor is crap. The Attorney General is the top legal officer. If the Solicitor General doesn't agree [with the position urged by civil rights groups] he has every legal right not to argue it, but the Attorney General and the President have to make the decision [about what arguments to make before the Supreme Court].

The Solicitor General ended by adopting the views of the civil rights groups. ${ }^{63}$ Similarly, when William Rehnquist was nominated to the Supreme Court in 1971, he was willing to defend his past activities in the Nixon Justice Department in unapologetic terms. To Senator Edward Kennedy's urging that "your client was the public as well," Rehnquist replied, "My client, in my position as the Assistant Attorney General for the Office of Legal Counsel, is the Attorney General and the president." ${ }^{64}$

The scandals associated with Watergate, which ultimately saw two successive Attorneys General go to prison for partisan manipulation of the Justice Department, brought a sharp swing of opinion in the opposite direction. In the spring of 1974, as the Watergate drama was entering its final stages, Senator Sam Ervin, hero of the Senate committee that investigated Watergate, proposed a bill to limit sharply presidential appointment and removal powers in relation to the Attorney General and the Justice Department so that the Justice Department would function "much like the regulatory commissions." Congress was unwilling to pursue such an extreme recourse, but it did register its distrust of the Justice Department by diffusing litigating authority more extensively among federal agencies and departments. ${ }^{65}$

In this atmosphere, President Ford felt obliged to pick an Attorney General "from outside the traditional political arena." 66 The man he picked, University of Chicago president Edward Levi, had made a point of disavowing partisan political ties and had no previous ties at all with Ford. ${ }^{67}$ In his confirmation hearings, Levi was asked about his degree of independence from the White House more than any other topic and gave repeated assurances of his intention to "give my independent judgment" in relation to "legality" and "the kinds of policies which are involved in the legality ...."68 Both Ford and Levi

63. Id. at $287-94$.

64. Hearings Before the Senate Committee on the Judiciary on the Nomination of William H. Rehnquist and Lewis F. Powell, Jr., to be Associate Justices of the Supreme Court, 92d Cong., 1st Sess. 48 (1971), quoted in BAKER, supra note 57, at 194.

65. See Removing Politics from the Administration of Justice: Hearings Before the Subcomm. on Separation of Powers of the Senate Comm. on the Judiciary, 93d Cong., 2d Sess. (1974).

66. The phrase belongs to Ford. See Gerald R. Ford, Attomey General Edward H. Levi, 52 U. CHI. L. REV. 284, 284 (1985).

67. Levi explained at his confirmation hearings that he had refused even to register with a political party as an Illinois voter, lest this compromise his image of impartiality at the University of Chicago. He was so unconnected with Ford that the two had never met before Ford interviewed him in connection with the appointment. BAKER, supra note 57, at 142.

68. Nomination of Edward $H$. Levi to be Attorney General of the United States: Hearings before the Comm. on the Judiciary, 94th Cong., 1st Sess., at 7. BAKER, supra note 57, at 142-44, notes that such intensive questioning about independence was not at all the previous historical norm, though it is understandable in light of Watergate. 
apparently felt particular constraint in their mutual dealings thereafter and maintained a formal distance.

The pattern continued under President Carter. Although Carter had long-standing personal ties to Griffin Bell, his nominee for Attorney General, Judge Bell had already been on the federal bench for fifteen years at the time of his nomination and had taken no role in Carter's presidential campaign. ${ }^{69}$ Nonetheless the Senate again grilled Bell on the degree of independence he expected to maintain from the White House. Bell repeatedly emphasized the need for independence, noting at one point that as Attorney General "the people are your client" and "if there's a conflict" with the President's preferences, "the people prevail." He insisted that he would rebuff all approaches from White House staff and resign rather than carry out a direct presidential directive he regarded as improper. Bell insisted he would organize the Justice Department as a "political neutral zone" and he seems to have made genuine efforts to "professionalize" and "depoliticize" the Department of Justice. ${ }^{70}$

Public statements about "independence" and "neutrality" might be discounted as convenient political rhetoric rather than a meaningful guide to administrative realities, but for two important facts. One was the new zeal of the press in pursuing questions of "tampering" or impropriety in the "post-Watergate era."71 This meant that affronted career lawyers, or lesser political appointees, could find ready means of embarrassing political superiors by leaking disputes about Justice Department actions to the press. Attorneys General and White House staffs had to be on their guard in an era when even "the appearance of impropriety" could develop into a major political headache. ${ }^{72}$

But there was also a second factor that gave life to protestations of "independence" at the Justice Department. This was the fact that the Justice Department already had important institutional traditions of legal professionalism and political independence-right along with political connections to the White House. These professional traditions are driven by the need of the Justice Department to maintain credibility with the courts, since much of the Department's work is ultimately dependent on litigation or prosecution before

69. BELL \& OSTROW, supra note 24 , at $63-66$, suggests that resistance to Bell's nomination really derived from his history as a southern judge not as a Carter intimate but Bell was sufficiently mindful of the "perception" of his intimacy with Carter that he resolved from the outset not to continue as Attorney General during Carter's run for reelection.

70. ClAYTON, supra note 58, at 143-45, describes the hearings and Bell's response. See also BAKER, supra note 57 , at $151-56$.

71. GARMENT, supra note 46 , at $58-82$, devotes an entire chapter to the phenomenon of "feeding frenzies" in the press over alleged scandals or abuses. Id. at 58-82.

72. Attorney General Bell, for example, had to endure what he calls his "darkest days as Attomey General," BELL \& OSTROW, supra note 24, at 208, when the press sensed a scandal in his decision to remove the Republican-appointed U.S. Attorney in Philadelphia in 1977, even though it is normal practice to replace U.S. Attorneys with new appointees at the outset of a new administration. The press sensed scandal because the incumbent Attorney charged that the removal was intended to deflect his investigations of a local Democratic congressman. Bell attributes the media flap to the fact that "in the afterglow of Watergate, the Caeser's wife, cleaner-than-a-hound's-tooth doctrine prevailed, and appearances became more important than reality." 
the courts. Moreover, even those aspects of the Department's work which do not directly involve litigation-such as advising federal agencies or the White House on their legal duties-still require competent lawyering by the Department, since those on the receiving end of legal advice need assurance that they can depend on its worthiness before the courts, should the matter enter into litigation at some later time. As a result, even the Nixon Administration, with all its partisan zeal, retained the Johnson Administration's Solicitor General in office for its entire first term. ${ }^{73}$ At the Office of Legal Counsel (originally known as the Office of Executive Adjudications), a tradition developed that one of the two deputies to the Assistant Attorney General in charge of that office should be a career attorney for the Department, protected from political pressure by civil service rules. And even in the Nixon Administration, the Office of Legal Counsel operated without much political interference. ${ }^{74}$

As the Justice Department placed more emphasis on its independent professionalism in the aftermath of Watergate, dealings between the Department and the White House inevitably became more delicate. This enhanced the importance of the White House Counsel's Office in several respects. First, the White House Counsel came to be seen as the sole respectable link between the White House and the formal legal machinery of the executive branch. Attorney General Levi would contact Philip Buchen about potentially sensitive departmental matters. Buchen's office, in turn, became a "buffer between the political world and the Justice Department."75 Attorney General Bell insisted on dealing only with the White House Counsel rather than other officials. ${ }^{76}$ Moreover, with the Justice Department held at arms length, the White House Counsel became a much more important source of independent guidance and information for the President. In some matters, the Justice Department seems to have been cut out of presidential deliberations altogether. More often, the Counsel's Office became an important, separate sounding board for White House deliberations on policies to be implemented by the Justice Department. ${ }^{n}$

The Reagan Administration, it is true, seems to have felt freer to depart from this pattern, as Watergate sensitivities receded with the passage of time. Reagan appointed two longtime personal associates to be Attorney General. In the first

73. Rebecca mae Salokar, The Solictror General, The Politics of Law 55 (1991), describes Solicitor General Griswold as an "ideological moderate."

74. Frank Wozencraft, OLC: The Unfamiliar Acronym, 57 A.B.A. J. 33, 36 (1971). James Michael Strine reports that the practice of retaining a career lawyer as deputy for OLC continued through the Carter and Reagan administrations. James Michael Strine, The Office of Legal Counsel: Legal Professionals in a Political System 76, n.35 (1992) (unpublished Ph.D. dissertation, Department of Political Science, Johns Hopkins University).

75. BAKER, supra note 57, at 146.

76. James Michael Strine has discovered memos in the Carter library in which lawyers at the Office of Legal Counsel at Justice protest to the White House Counsel that he must more rigorously enforce the rule that White House staff not communicate to Justice except through the Counsel. Counsel Robert Lifshutz subsequently fired off an angry memo to Press Secretary Jody Powell, when Powell asked for OLC guidance on whether he could issue press passes for Soviet journalists. Strine, supra note 74, at $117-18$.

77. BAKER, supra note 57, at 146-47, 161-63. 
term, White House Counselor Edwin Meese felt free to meet on his own with Justice Department officials, discounting the advice of the much subordinated actual Counsel, Fred Fielding. ${ }^{78}$ When Meese, himself, became Attorney General, he continued to work closely with the White House. But the Reagan Administration paid a price for this aggressive posture at the Justice Department. Meese's personal financial troubles may have been bad luck but his aggressive effort to change the law certainly provoked unwanted press attention. Among other things, the large series in The New Yorker by Lincoln Caplan, castigating the Meese Justice Department for pressuring the Solicitor General-and featuring a long number of leaked claims from career attorneys at Justice-helped to revive the issue of "partisan manipulation." 79

Even before the end of the Reagan Administration, there was a return to a more cautious public approach. The appointment of Richard Thornburgh, a relative outsider, as Attorney General signaled a return to earlier patterns. President Bush retained Thornburgh for almost two years and relied on Counsel Gray as a go-between. When William Barr was nominated to be Assistant Attorney General for Legal Counsel, after previous service with Gray in the Reagan White House, Senators grilled him on his "independence." And Barr replied in the spirit of Levi and Bell, promising to form his own judgments. ${ }^{80}$ When Barr was promoted to the top job at Justice, he was asked to give similar assurances-and did so. ${ }^{81}$

The problem is that no White House can afford to be entirely indifferent or aloof from the operations of the Justice Department. That is because the Justice Department itself is entangled in major issues of domestic politics for which, quite understandably and properly, voters hold the president responsible.

78. Meese was directly involved in deliberations leading to the politically disastrous change of policy on tax exemptions for segregated schools which ultimately reached the Supreme Court in Bob Jones v. Regan, 461 U.S. 574 (1983). A detailed account of the internal deliberations between Meese and Justice and Treasury officials is provided in Eric A. Stern, The Case of the Segregated Schools (unpublished manuscript case study of the Kennedy School of Government, Harvard University) (April 18, 1983) (catalogued as C 14-83-531).

79. Lincoln Caplan, The Tenth Justice, 63 THE NEW YORKER, Aug. 10, 1987, at 29; Lincoln Caplan, The Tenth Justice (II), 63 THE NEw YORKER Aug. 17, 1987, at 30. Both are now in a single volume, THE TENTH Justice, The Solicitor General AND the Rule of LAw (1987).

80. Confirmation Hearings on Federal Appointments, Hearings before the Senate Comm. on the Judiciary, 101st Cong., 1st Sess., Part I 84-88 (1989) (statement of William Barr) (Barr: "Attorney General Thornburgh .... told me what he expected of me ... someone ... who would give him intellectually honest, objective advice as to what the law is .... I don't believe it is the role of the Office of Legal Counsel to try to push the law one way or the other, or to play an activist role in the evolution of the law.").

81. Confirmation Hearings on Federal Appointments: Hearings Before the Senate Comm. on the Judiciary, 102d Cong., 1st Sess., Part II, 142 (1991) (statement of Chairman Biden: "The Attorney General is a member of the President's administration but his allegiance is not to the President alone .... The Attorney General is more properly considered the people's lawyer. His allegiance must be to the public . . . he must be prepared to tell the President that a proposed course of action would violate the Constitution or the laws ... even when that advice is not what the President wishes to hear. ... [T] he Attorney General has unique responsibility to the public that requires him to maintain independence from the President's personal and political interests.") (statement of William Barr: "when an issue is brought to me, the first thing I do analytically is say, 'let's take the politics out of it."') 


\section{$\mathrm{V}$ \\ THE INEVITABILITY OF LEGAL POLITICS}

The rise of pressures associated with "ethics" laws has given the White House a need for a substantial in-house legal staff. The delicacy of White House dealings with the Justice Department has heightened the usefulness of this staff in other areas. But the underlying importance of the Counsel's Office finally rests on the dramatically increased importance in recent times of constitutional issues for the occupant of the Oval Office.

The prominence of constitutional issues in national politics is so much a feature of recent decades that it is easy to forget how novel this pattern really is in historical terms. Through most of U.S. history, the Supreme Court did not play anything at all like the role it has now come to play in national policymaking. It was not until the 1960 s that the Supreme Court began to apply the Bill of Rights to the states in a systematic way and to give real bite to the Equal Protection Clause of the Fourteenth Amendment. There were certainly controversial decisions of the Court before the 1960 s. But they usually did not tie the hands of politicians in significant ways. For example, Chief Justice Marshall's endorsement of the Bank of the United States in McCulloch $v$. Maryland ${ }^{82}$ did not prevent President Jackson from pursuing his successful "war on the Bank." 83 On the few occasions when the Supreme Court sought to put a serious brake on national policy-as in the controversy over slavery in the 1850s and over New Deal undertakings in the 1930s-the Court was overridden by determined national majorities and never sought to challenge the new dispensation thereafter. ${ }^{84}$

By contrast, the list of issues that have agitated constitutional law over the past three decades is imposingly long. The bitter dispute, since Roe $v$. Wade, ${ }^{85}$ over the legal status of abortion must head the list. But there have also been bitter disputes about a myriad of other issues including school integration and "forced busing", affirmative action and "quotas", the "rights of the accused" and the countering demand to "stop tying the hands of the police", capital punishment, aid to religious schools and accommodation of religion in public settings, free speech protection for pornography and libel, due process guarantees for disruptive students in public schools, judicial supervision of prisons and state psychiatric hospitals, and judicial direction of election districting.

What is striking about the controversies provoked by the Supreme Court in the last thirty years is not only the number of issues but the extent to which they have dragged on, in one form or another, for decades. In part, this reflects the

82. 17 U.S. (4 Wheat.) 316 (1819).

83. Alfred Kelly, Winifred harbison and Herman Belz, The american Constitution, ITS ORIGINS AND DEVELOPMENT 212-214 (6th ed., 1983).

84. See BRUCE ACKeRMAN, We tHE PEOPLE (1991) (for an argument that the resolution of these disputes was so convincing as to amount to an informal, but nonetheless binding, popular amendment of the Constitution).

85. 410 U.S. 113 (1979). 
simple depth of feeling on each side in many of these issues. It also seems to reflect the fact that the Court, itself internally divided over most of this period, has been unable or unwilling to impose clear, decisive resolutions to most of these issues. Even the landmark decisions left a great deal for each side to fear or to hope for in the future and subsequent decisions often traveled unpredictable lines, encouraging renewed efforts to rattle the Court into retreating or goading it to further initiatives. ${ }^{86}$

Participation by organized advocacy groups in Supreme Court litigation offers a neat register of the increasing-and enduring-polarization of opinion on constitutional issues. By the end of the 1960s, liberal advocacy groups, like the ACLU and the NAACP, were involved in almost half of all cases before the Supreme Court, urging their views through amicus briefs when not directly representing a party to the case. ${ }^{87}$ Conservative advocacy groups began to spring up, tripling their rate of participation between 1969 and 1981, until their levels of participation on key issues like abortion and "civil rights" nearly matched that of the older liberal groups. ${ }^{88}$ The monumental political battles over the Supreme Court nominations of Robert Bork and Clarence Thomas simply dramatized the underlying reality: constitutional law had become a fierce political battleground in which even one additional vote on the Supreme Court might make a decisive difference.

Two factors intensified this battleground and assured it presidential attention. First, the polarization of opinion on so many constitutional issues entered into the growing ideological polarization between the main political parties. In the 1950 s and 1960s, for example, Southern Democrats were the most vehement critics of Brown v. Board of Education and early efforts at school integration, while leading figures in the civil rights coalition included many Republicans. ${ }^{89}$ By the 1970s, an ongoing realignment saw Republican presidents denouncing "quota" schemes and demanding limits on "forced busing," while Democratic presidential candidates were more or less obliged to defend such policies as party orthodoxy. ${ }^{90}$ As late as 1976, the Republican platform endorsed the Equal Rights Amendment while the Democratic platform passed over the abortion

86. See Martin Shapiro, The Supreme Court from Burger to Rehnquist in THE NEW AMERICAN POLITICAL SYSTEM 84-85 (Anthony King ed., 2d ed., 1990).

87. Karen O'Connor \& Lee Epstein, Court Rules and Workload: A Case Study of Rules Governing Amicus Curiae Participation, 8 JUST. SYs. J. 35, 42 (1983).

88. Karen O'Connor \& Lee Epstein, The Rise of Conservative Interest Group Litigation, $45 \mathrm{~J}$. POL. 479, 481 (1983).

89. Hugh Davis Graham, The Civil Rights Era 29-30 (1990), notes that in the 1960 election, Republican candidate Nixon was a "card carrying member of the NAACP," who "enjoyed a favorable relationship with national civil rights leaders," while candidate Kennedy "had no reputation as a civil rights advocate" and was attacked by Nixon, in one of their 1960 debates, for running with a vicepreseidential candidate from the South who had voted against civil rights measures in the past. CHARLES AND BARBARA WHELEN, THE LONGEST DEBATE, A LEGISLATIVE HistoRY OF THE 1964 CIVIL RIGHTS ACT $29-70$ (1985), describes one crucial phase in that debate under the apt heading, "Republicans to the rescue."

90. See Graham, supra note 89 , at $443-449$ n.92. 
issue in silence. ${ }^{91}$ Since 1980 , successive Republican platforms have pledged firm support to the pro-life cause while Democratic platforms have pledged equally strong fealty to the pro-choice side..$^{92}$ As never before, new presidents come to office with constitutional commitments-or at least with organized constituencies seeking action on a well-developed agenda for constitutional law.

The partisan and ideological divisions were exacerbated, in turn, by institutional divisions, as elections regularly seemed to yield Republican presidents facing a Democratic-controlled Congress. This factor added an urgency to ongoing constitutional disputes about presidential prerogatives and the separation of powers. In principle, Democratic presidents may have as much reason to assert and defend executive prerogatives as Republicans, and certainly have done so in the past. But entrenched Democratic majorities in Congress were bound to take a much more dismissive view of presidential claims with the White House so regularly in Republican hands. ${ }^{93}$ By the same token, hard lines in constitutional doctrine were bound to seem more appealing to Republican presidents lacking a cooperative majority in Congress. ${ }^{94}$ Moreover, questions about presidential prerogatives or separation of powers were sometimes entangled with other constitutional or legal issues, as with the abortion counseling regulations that came before the Supreme Court in Rust v. Sullivan. ${ }^{95}$

In sum, presidents could not readily ignore constitutional issues. They were pressed to take sides, to advance an agenda. ${ }^{96}$ Of course, presidents always have competing concerns and often find it politically prudent to pass over tempting occasions for constitutional battle. The Counsel's Office is only one participant in presidential deliberations on how, when or whether to enter a constitutional dispute. But it is clearly an important participant.

\section{COUNSELING CONSTITUTIONAL STRATEgY}

The most obvious way for the president to influence constitutional law is by directing the Justice Department to take certain stands in legal arguments before the courts. Presidents have, in fact, taken a direct interest in the briefs filed by the Solicitor General. President Truman is known to have intervened in the Solicitor's arguments in Shelley v. Kraemer ${ }^{97}$ (holding racially restrictive covenants unenforceable), and President Eisenhower influenced the Solicitor's

91. 2 NATIONAL PARTY PLATFORMS 925-27 (1976 Democratic Platform) \& 74-76 (1976 Republican Platform) (Donald Bruce Johnson ed., 1978).

92. NATIONAL PARTY CONVENTIONS, 1831-1984, at 149 (1984 Democrats) \& 155 (1984 Republicans) (Eva Marie Socha ed., 1987); NATIONAL PARTY PlatForms of 1980, at 62 (Democrats) \& 183, 203 (Republicans) (Donald Bruce Johnson ed., 1982).

93. Benjamin Ginsberg \& Martin Shefter, Politics By OTHer Means 16-19 (1990).

94. Id.

95. 118 S. Ct. 1759 (1991).

96. See generally CLAYTON, supra note 58.

97. 334 U.S. 1 (1948). 
brief in Brown v. Board $I I^{98}$ (on the means of enforcing the Court's earlier ruling against school segregation). ${ }^{99}$ In the Carter Administration, the White House was closely involved in supervising briefs to be filed in Regents of the University of California v. Bakke $e^{100}$ (on the permissible degree of racial preference in higher education admissions). The President's involvement was undertaken in a rather public way at the insistence of Vice President Mondale and Health, Education and Welfare Secretary Califano. ${ }^{101}$

In the Bush Administration, the White House openly prevailed on the Solicitor General to modify the government's position in litigation to desegregate Mississippi's system of higher education. The White House in this instance acted in public view, in a case that had been handled by the Justice Department from the beginning and it intervened after a meeting between the President and black college officials from Mississippi who were essentially parties to the case. ${ }^{102}$

Since the White House interventions in these cases secured changes in the Solicitor General's briefs and did so without generating any great public controversy or criticism, it might appear that the White House has broad authority to overrule the Solicitor. But these cases are almost surely exceptions to the general pattern. The White House in each case dealt with constituencies who were viewed in sympathetic terms by the liberal advocacy groups who had been loudest and most successful in denouncing the corruption of the Justice Department by a "partisan" White House. In many circumstances, however, once an issue reaches the Supreme Court, it may be politically awkward for the White House to try to direct the Solicitor General on how to proceed with the government's argument, given the professional pride of attorneys in the Solicitor's office and the readiness of critics to seize on White House interference as introducing "partisan" concerns into constitutional adjudication. ${ }^{103}$ More-

98. 349 U.S. 294 (1955).

99. See Philip Elman, The Solicitor General's Office, Justice Frankfurter and Civil Rights Litigation, 1946-1960: An Oral History, 100 HARV. L. REV. 817 (1987). It is probably no coincidence that both were cases that did not emerge from previous federal positions but rather from private litigation by advocacy groups, where the Justice Department was pressed to take a position as amicus at a later stage.

100. 438 U.S. 265 (1978).

101. This episode is by now an oft-told tale. Joseph Califano gives one version, JOSEPH CALIFANO, GOVERNING AMERICA 237-43 (1981); slightly different is the account in Bell \& Ostrow, supra note 24, at 28-32.

102. Ruth Marcus, Bush Shifts Stand on Aid to Black Colleges, Administration Now Supports Increased State Funding in Mississippi Case, WASH. POST, Oct. 23, 1991, at A6; Ruth Marcus, Some Justices Appear Skeptical of Mississippi Colleges' Racial Split, WASH. POST, Nov. 14, 1991, at A4. Solicitor General Kenneth Starr had argued in his initial brief to the Supreme Court in U.S. v. Mabus, that Mississippi would not be responsible to provide additional funding for traditionally black colleges in the state higher education system. After the President's intervention, Starr's reply briefs took the opposite line on this issue, urging that the state should supply additional funding. The case was finally decided as U.S. v. Fordice, 112 S. Ct. 2727 (1992) (Mississippi having elected a new governor in the interim).

103. Charles Fried, who served as Solicitor General in Reagan's second term, reports in his memoir of the experience that career officials in the Solicitor's office "thought [they] should produce a recommendation or a draft brief, which, if it was done properly, no mere political appointee like myself could in good faith do other than accept." CHARLES FRIED, ORDER AND LAW, ARGUING THE REAGAN REVOLUTION 37 (1991). 
over, the Supreme Court did not respond well to the arguments ultimately submitted by the Solicitor in these cases and the interventions seem to have generated resentment within the Justice Department. ${ }^{104}$

Such interventions may be most significant as a reminder of ultimate presidential authority and they may give more leverage to the Counsel's Office in following cases before they reach such an advanced stage. The president need not have a direct meeting with the Solicitor General for the Counsel's Office to obtain information about the drafting of briefs and to send discrete signals back to the Solicitor's Office through various informal channels. A sizable permanent legal staff at the White House makes this easier to do. In the Reagan Administration, Attorney General Meese was committed to an active program of conservative-oriented change in constitutional law and was actively involved in deliberations within the Justice Department on the content of the Solicitor's briefs to the Supreme Court. Meese probably did not need direction from the White House and, having older and closer ties to the President than anyone on the White House staff by that time, probably would not have taken much direction from the White House. But his successor, Richard Thornburgh, was a remote figure from the standpoint of the Justice Department ${ }^{105}$ and a sizable Counsel's staff was probably of considerably more importance in this setting.

The president's position on any particular issue is more likely to prevail, of course, if it comes before like-minded judges. So another obvious way for presidents to try to influence the direction of constitutional law is through appointments to the federal courts. The Reagan Administration, like the Nixon Administration before it, certainly made no secret of its desire to alter the shape of the law through the appointment of judges and Justices with a conservative outlook. In both administrations, the Justice Department seems to have played the principal role in selecting nominees, even for Supreme Court positions. ${ }^{106}$ But the White House Counsel's Office can play an important role here, too, both as a source of separate opinions and as a more flexible actor (because a less visible and less accountable actor) than the Justice Department.

So, for example, when William Barr was nominated to be Attorney General, shortly after the brutal fight over the Clarence Thomas nomination, he was questioned closely by the Senate Judiciary Committee about the role of the Justice Department in seeking out personal information to discredit Anita Hill, who had accused Thomas of sexual harassment. Barr stoutly denied any Justice Department involvement in feeding information to Republican Senators on the

104. Fried also notes that Justice Powell's controlling opinion in Bakke rejected the "precise submission" of the Solicitor's brief on whether universities can "take race into account to remedy the effects of societal discrimination." Id. at 200. For the Court's response in Fordice, see the anguished concurrence by Justice Thomas.

105. DOUglas KMIEC, THE ATtORney General's LaWyer, Inside THE MEESE JUSTICE DEPARTMENT 148 (1992), complains that Thornburgh maintained a "Howard Hughes-like environment" of isolation and never responded in any way to the reports which Kmiec sent him on OLC's handling of issues on its docket.

106. Clayton, supra note 58 , at 40. 
Judiciary Committee but conceded that lawyers in the White House Counsel's Office may have done so. ${ }^{107}$ This sort of activity may not require trained lawyers, but it is hardly surprising that, following the fiasco of the Bork nomination, the Bush Administration wanted a White House unit capable of providing close support to Supreme Court nominees. The role is all the more logical as the Counsel's Office has developed great experience in handling FBI reports for executive nominees, ${ }^{108}$ and similar questions arise on how to evaluate such materials and on what terms to disclose their contents to congressional committees. Press accounts of President Clinton's deliberations before the nomination of Ruth Ginsberg to the Supreme Court indicate that Counsel Bernard Nussbaum played a key role in the White House deliberations, much more so, it appears, than the Justice Department. ${ }^{109}$

But these most obvious paths to influencing constitutional law may not be the most important. Constitutional law is not simply a set of pronouncements from the courts. And even the judge-made law is influenced by a much wider context than the briefs immediately presented or the personal inclinations of the judges. Constitutional issues often arise in the course of operations in other parts of the executive branch. When a constitutional question arises (or an important statutory question) regarding an agency's authority to undertake a proposed action, the matter is usually referred to the Office of Legal Counsel ("OLC")in the Justice Department. Referrals of this sort can take place without any involvement from the White House or the White House Counsel's Office. Once an issue is under consideration at OLC, it is considered a breach of decorum for the White House to review draft opinions. In most cases, OLC does proceed quite independently. ${ }^{110}$ Nonetheless, the White House Counsel's Office can sometimes make a difference in the maneuvering that takes place before a question is formally submitted to OLC.

The White House undoubtedly has some leverage on how and whether agencies submit requests for legal guidance to OLC. For example, James Michael Strine has documented that during the Carter Administration the White House Counsel's Office was closely involved in negotiations between the Department of Labor and the Department of Transportation to determine appropriate limits on the application of minimum wage laws to local transit systems. ${ }^{111}$ Lawyers in the affected departments were divided on the applica-

107. Confirmation Hearings-William P. Barr, supra note 80 at 47.

108. STEWART, supra note 37 , notes that Counsel Fielding reviewed more than 2500 reports on executive appointments.

109. Richard L. Berke, Clinton Names Ruth Ginsberg, Advocate for Women, to Court, N.Y. TIMES, June 14, 1993, at A1.

110. KMIEC, supra note 105 , at 207 , insists that "OLC would never permit the prescreening of its draft opinions."

111. Strine, supra note 74, at 133-90. Griffin Bell reports that the White House was also closely involved in deliberations on whether, under the First Amendment, funds could be distributed to religious schools under the Comprehensive Employment and Training Act. See 29 U.S.C. $\$ 801$ (1985). OLC lawyers originally ruled against doing so, but Vice President Mondale and Domestic Council Chief Stewart Eizenstadt prevailed on President Carter to overrule OLC. The new position was reflected in 
tion of Supreme Court decisions on the Tenth Amendment, and the Counsel's Office involved itself in part for the very purpose of avoiding an overly formal resolution of the dispute by OLC. ${ }^{112}$

In the Bush Administration, the White House certainly did not interfere with the FBI when it sought guidance on whether it would be unlawful to apprehend terrorists or drug traffickers on foreign soil without the consent of the host country. The OLC returned an opinion declaring such apprehensions to be perfectly legal-though on the very same question, the Assistant Attorney General for Legal Counsel had given a diametrically opposed ruling in the Carter Administration. ${ }^{113}$ On the other hand, the Bush Administration did not seek guidance from OLC on whether, as prominent conservative legal advocates had urged, the White House could assert a line-item veto by treating appropriation measures as a collection of separate "bills." Lawyers in the White House Counsel's Office had already determined that the chances of a favorable ruling from OLC were too unlikely. ${ }^{114}$

Nothing in protocol prevents the White House Counsel from directly phoning the Assistant Attorney General for Legal Counsel to ask about the likelihood of one or another legal argument being sustained by OLC. For example, Douglas Kmiec's memoir, which is quite insistent about OLC's refusal to circulate draft opinions for White House review, reports a number of informal advance inquiries from the White House Counsel on what OLC would be likely to say if a question were formally submitted. ${ }^{115}$ These discussions may sometimes give the Counsel a chance to suggest lines of argument that the White House would like to see adopted. As the Counsel's Office is in constant communication with OLC on other presidential business, there are many opportunities to exchange views. Nor

Department of Labor regulations subsequently ruled unconstitutional by the Seventh Circuit Court of Appeals; Justice did not appeal the decision. BELL \& OsTROW, supra note 24, at 24-28.

112. BELL \& OSTROW, supra note 24 , at 181-86.

113. See "Testimony of William Barr, Assistant Attorney General for Legal Counsel," FBI Authority to Seize Suspects Abroad: Hearings Before the Subcomm. on Civil and Constitutional Rights, Comm. on the Judiciary, U.S. House of Representatives, 101st Cong., 1st Sess. 2-4 (1989) (summarizing the change in OLC rulings and explaining that the new opinion was issued after "the FBI asked the Office of Legal Counsel ... to reexamine its 1980 opinion.") Barr insisted that the new ruling did not represent a "changed Department of Justice policy" because it was "strictly a legal analysis of the FBI's authority as a matter of domestic law ... . The 1989 opinion takes no position, supporting or opposing, as a matter of policy, the use of the FBI or any other executive branch officials to make apprehensions in contravention of customary international law." Id. at 5. Barr did not explain why this "strictly legal analysis" came to the opposite conclusion of the legal analysis offered by OLC in 1980. He also insisted that neither the 1980 nor the 1989 opinions could be made available to Congress (nor to anyone else outside the executive branch), because these opinions had to remain "confidential . . based on the very same principles that the attorney-client privilege in general is based upon." Id. at 4. Many OLC opinions have been published over the years (as Barr acknowledged at the hearing), but these were not among them.

114. Arguments on behalf of the veto by conservative advocates are collected in L. GORDON Crovitz, Pork Barrels and Principles: The Politics of THE Presidential Veto (National Legal Center for the Public Interest ed., 1988), and elaborated in L. Gordon Crovitz, The Line Item Veto, 18 PEPP. L. REV. 43-55 (1990). President Bush acknowledged he did not have the authority to exercise a line item veto in a public speech on budget procedures on March 20, 1992.

115. KMIEC, supra note 105 , at $91,207$. 
are these exchanges limited to formal consultations between the Counsel, personally, and the actual Assistant Attorney General for Legal Counsel. Assistants and staff attorneys at both the White House and the Justice Department are also in regular contact on common projects.

It is difficult to determine the direction of influence in these communications, which are usually conducted by telephone or in personal meetings rather than by formal exchange of memos. It is in the interest of the Counsel's Office to give the appearance that the White House is abiding by detached, professional advice from OLC. And it is in the interest of OLC to foster the same image. On the other hand, OLC attempts to avoid generating the perception in the White House that it is a balky obstacle to White House policy aims. In the past, Assistant Attorneys General have impressed the White House enough to gain impressive promotions: Antonin Scalia and William Rehnquist, both of whom served as Assistant Attorney General at OLC in the 1970s, were rewarded with seats on the Supreme Court. President Bush's initial appointee at OLC, William Barr, was subsequently promoted to Attorney General while Barr's successor at OLC was appointed an appellate judge at a young age. ${ }^{116}$ The OLC probably does not need to be reminded of the advantages of cooperating with the White House. An enlarged White House Counsel's Office, however, makes it easier for OLC to learn what the White House would like or at least to discern the legal traps of greatest concern to the White House.

The importance of such links goes beyond the immediate content of OLC rulings. Since issues initially framed by OLC for the guidance of federal agencies may eventually be drawn into constitutional litigation, the OLC's interim resolution in effect sets an agenda for the Supreme Court. This was the pattern, for example, in the litigation that led to the Court's decisions in Garcia v. San Antonio Metro Transit Authority ${ }^{117}$ (on federal power under the Tenth Amendment), in Rust $v$. Sullivan ${ }^{118}$ (on withholding aid to family planning clinics that advised clients on abortion), and in United States v. Humberto Alvarez-Machain ${ }^{119}$ (on circumventing formal extradition procedures to apprehend criminals on foreign soil).

VII

\section{Counseling Presidential ACtion}

Legal advice for the White House is most important when the president must act directly in his own name. Here, too, the OLC usually plays an important role in advising the president. But the White House Counsel's Office can be an

116. J. William Luttig was appointed a judge on the Fourth Circuit Court of Appeals.

117. 469 U.S. $528(1985)$.

118. 118 S. Ct. 1759 (1991). KMIEC, supra note 105, at 86-88, describes reconsideration of a 1970 law by OLC-at the prompting of private, pro-life advocacy groups-which led the White House to direct the Department of Health and Human Services to draft the new regulations ultimately challenged in Rust.

119. 112 S. Ct. 2188 (1992). 
important link between OLC and the White House. And on the most sensitive matters, the judgment of the Counsel may be relied upon much more than the legal arguments of OLC.

The president's role in the legislative process poses legal questions with most regularity. Since the era when Samuel Rosenman advised Presidents Roosevelt and Truman, every Counsel has spent much time in scrutinizing (and often in drafting) presidential messages to Congress, with special attention to signing statements or veto statements on enrolled bills. Considerations of policy and politics are, of course, particularly hard to separate from the legal and constitutional issues that can arise in presidential deliberations on new legislation. A formalized review process, coordinated by the Office of Management and Budget, is designed to ensure that the president will have the benefit of policy concerns affecting new legislation from all relevant agencies and departments within the executive establishment. But by virtue of his proximity to the Oval Office, the Counsel's words are always among the last words the president hears.

On legal questions, the Justice Department is always consulted and may have stronger or more developed views than the Counsel, but the Counsel's leanings may affect how seriously OLC's advice is weighed at the White House. Charles Cooper, who served as Assistant Attorney General for Legal Counsel toward the end of the Reagan Administration, complained that OLC advice was frequently discounted by the White House. In Cooper's view, the White House lawyers were more concerned with immediate political goals than with the constitutional doctrines on presidential power emphasized by OLC. ${ }^{120}$ Cooper's successor, Douglas Kmiec, notes that OLC on one occasion prepared an elaborate constitutional argument for a veto message on the South Africa sanctions bill. Reagan vetoed the measure, but the Counsel's Office deleted the constitutional arguments from the message, and Congress subsequently voted to override the veto. $^{121}$

A recent study of OLC by political scientist James Michael Strine argues that OLC became more eager to assert legalistic positions on the separation of powers through the 1970 s and 1980 s as the Justice Department, in general, became more removed from the immediate political concerns of the White House-and this, in turn, made presidents more inclined to rely on the more accommodationist advice of the Counsel's Office. ${ }^{122}$ It is not inevitable that the Counsel's Office will always be more inclined to compromise with Congress. President Bush's Counsel, C. Boyden Gray, seems to have championed a strong view of presidential prerogatives, in full accord with Justice Department lawyers

120. "Preserving presidential prerogatives, protecting the office itself, was not viewed as that important. Far more important was getting a good political result or avoiding a bad one." Quoted in TERRY EASTLAND, ENERGY IN THE EXECUTIVE 330 n.24 (1992).

121. KMIEC, supra note 106, at 56. The reenacted measure, The Comprehensive Anti-Apartheid Act of 1986 , Pub. L. No. $99-440,100$ Stat. 1086, is codified in 22 U.S.C. $\$ 5001$ (1988).

122. Strine, supra note 74 , at 191-252. 
and the Counsel's Office devoted considerable effort to elaborating constitutional objections (on separation of powers grounds) in presidential veto statements. ${ }^{123}$

Gray indeed went so far as to voice a public protest against a proposed legislative deal, allowing a congressional veto mechanism to win support for congressional funding of aid to the Contra rebels in Nicaragua. Gray warned that this would resemble an unconstitutional legislative veto and set a dangerous precedent for congressional checks on presidential power in foreign affairs. ${ }^{124}$ But this may have been the exception that proves the rule. The arrangement with Congress was negotiated by lawyers for Secretary of State James Baker, and Gray was evidently kept out of these negotiations so that Baker's team would not have to deal with Gray's constitutional objections. ${ }^{125}$ In the end, lastminute cautions from Gray did not prevent President Bush from signing the Contra funding bill, and Gray was scolded for voicing his objections outside the White House. ${ }^{126}$

Where presidents are determined to act, the Counsel has neither the legal authority nor the career incentives to stand in the way. Perhaps for this reason, presidents have leaned much more on the Counsel's advice in moments of crisis, when the president must take direct action on his own. During the Mayaguez affair, for example, President Ford had to consider not only the diplomatic and military issues posed by the seizure of a U.S. ship by the communist government of Cambodia. He also had to consider questions of presidential prerogative, complicated by the passage of the War Powers Resolution in 1973. White House logs showed that Ford consulted continuously with his Counsel Philip Buchen, but the President did not meet at all with Attorney General Edward Levi during the course of the crisis. ${ }^{127}$ It may be that Ford did not want to put Levi in the position of having to argue against measures on which the President was already determined. Clearly, the President was more confident and comfortable relying on his Counsel. And it seems likely that Ford's decision to direct air strikes against communist forces, without consulting Congress in advance, was supported by the Counsel's interpretations of the War Powers Resolution and the President's constitutional authority. It is unclear, however, whether the Counsel

123. Chuck Alston, Bush Crusades on Many Fronts to Retake President's Turf, CoNG. Q. WKLY REP., Feb. 3, 1990, at 291 (William Barr, then heading the OLC at Justice, is quoted in regard to increased cooperation with White House Counsel's Office on separation of powers issues: "The Reagan administration never had this kind of cohesion." Id. at 292). Strine, supra note 74, at 298, offers similar characterizations.

124. David Hoffman \& Ann Devroy, Bush Counsel Contests Contra Aid Plan, Gray Fears Pact with Congress May Infringe on Presidential Power, WASH. POST, Mar. 26, 1989, at A5.

125. Id.

126. Hoffman, supra note 33 .

127. BAKER, supra note 57, at 147-49, notes the dramatic contrast between Attorney General Robert Kennedy's constant attendance at White House deliberations during the Cuban Missile Crisis and Levi's complete absence. Baker acknowledges that the contrast "raises the disturbing possibility that Presidents appoint Neutral officers [to head the Justice Department] in response to external demands and then proceed to circumvent them when their legal assessments are unwelcome." Id. at 149. Levi's distance during the Mayaguez affair is the more striking because, as Baker notes, records show that Ford did meet frequently with Levi on many other occasions outside formal Cabinet meetings. Id. at 149-50. 
advised him that the War Powers Resolution was inapplicable to these circumstances or simply that it was always inapplicable because unconstitutional. ${ }^{128}$

During the Bush Administration, the White House Counsel presided over several meetings of top officials from the Defense Department and the State Department, along with top officials from OLC, to consider the legal options of the President in a particular foreign crisis. The White House never took a stand contrary to the advice of OLC. But the fact that the White House Counsel presided over the meetings was a tacit acknowledgement that OLC could not simply impose its own views. ${ }^{129}$

The weight of the Counsel's Office was revealed in a less dramatic incident that developed in the last months of the Bush Administration, when President Bush sought to impose a direct order on the U.S. Postal Service. The Service wanted to appeal an adverse decision by the Postal Rate Commission on proposed rate hikes. When the Justice Department declined to argue the Service's appeal, the Postal Service sought to file appeal briefs on its own. President Bush, asserting his executive authority over a nominally "independent" service, ordered the Postmaster General to desist from the appeal. ${ }^{130}$ When the Board of Governors of the Postal Service expressed their disagreement, President Bush reasserted his authority in a letter signed by Counsel C. Boyden Gray. ${ }^{131}$ The White House in this instance was backing a position favored by the Justice Department. But the position certainly had more weight coming from the President. ${ }^{132}$ As always, the Counsel's letter had authority only because it could present itself as the President's view. Yet it is a fair question whether the President would have committed himself to such a strong position on an arcane issue without the prompting of a Counsel's Office that had been eager to undermine the "independence" of so-called "independent" agencies. In the end, the position was too extreme for the D.C. Circuit Court of Appeals, which ruled in subsequent litigation on behalf of the Postal Service's right to pursue litigation independent of Justice Department consent or White House approval. ${ }^{133}$

128. Lloyd Cutler insists that, following the enactment of the War Powers Resolution over President Nixon's veto in 1974, "all subsequent Presidents have challenged" its constitutionality. Lloyd Cutler, The Constitutional Sharing of the War Power, 11 GEO. MASON U.L. REV. 221 (1988).

129. Interview with C. Boyden Gray (May 12, 1993). Gray explained that the White House Counsel had to chair these meetings, "because Justice is just one of the departments at the meeting."

130. See Neal Devins, Political Will and the Unitary Executive: What Makes an Independent Agency Independent?, 15 CARDOzo L. REV. 273 (1993).

131. Lawyers in Counsel's Office say that considerable thought was given to whether the letter should be signed by President Bush, but it was finally decided that such a long legal argument would seem odd coming directly from the President.

132. It was still thought more appropriate to issue the letter in the President's name rather than through the Justice Department, because the Justice Department would, in effect, have been ruling in its own case (on the underlying question of litigating authority) and the President's name would carry more authority.

133. See Mail Order Ass'n of America v. U.S. Postal Service, 986 F.2d 509 (D.C.Cir. 1993). To prevent the White House from undoing this decision, a federal district judge shortly thereafter issued an order prohibiting President Bush from removing the Chairman of the Board of Governors of the Postal Service. See Mackie v. Bush, 809 F.Supp. 144 (D.D.C. 1993). 
The new Clinton Administration also invoked the legal advice of the White House Counsel in a matter that touched on presidential prerogatives in an unusual setting. President Clinton appointed his wife, an experienced lawyer, to chair a task force to assess major proposals for health care reform. Advocacy groups for the medical profession protested that the task force meetings should be open to the public, under the requirements of the Federal Advisory Committee Act ("FACA"). ${ }^{134}$ Clinton White House Counsel Bernard Nussbaum then issued a legal memorandum, under his own name, arguing that Mrs. Rodham Clinton was the equivalent of a government official and her meetings with other government officials in the task force could remain closed to the public under the FACA exemption for meetings limited to government officials and employees.

In subsequent litigation, the federal district court in Washington, D.C., rejected the Counsel's reasoning, ruling that Mrs. Rodham Clinton could not be a federal official or employee within the terms of FACA and some, at least, of the task force meetings must therefore be open to the public. ${ }^{135}$ The D.C. Circuit Court of Appeals overruled this decision, however. ${ }^{136}$ The court held that FACA must be interpreted in a more accommodating spirit, allowing meetings with the First Lady to remain closed to the public under the FACA exemption for meetings limited to government officials and employees, as the White House Counsel had claimed. But the court rested this conclusion solely on the ground that if FACA were not interpreted to cover the First Lady, the statute might be considered an unconstitutional intrusion on executive privilege, which is supposed to secure advice to the president from outside scrutiny. A concurring opinion, rejecting this interpretation of the First Lady's status under FACA as "overly strained," indeed argued that FACA should be held unconstitutional as applied to advisory groups organized to give direct advice to the president. Yet the government itself was clearly reluctant to make this argument, which presumably would have raised some hackles in Congress. ${ }^{137}$

The decision proved awkward in another way. In a footnote, the Court raised, without resolving, the question of whether Mrs. Rodham Clinton, if

134. 86 Stat. 770 (1972) (codified at 5 U.S.C. $\$ 1$ (1988)).

135. Association of American Physicians and Surgeons, Inc. v. Clinton, 813 F.Supp. 82 (D.D.C.1993).

136. Association of American Physicians and Surgeons v. Clinton, 997 F.2d 898 (D.C.Cir. 1993).

137. The majority opinion notes:

The government, only at oral argument, and rather tentatively, suggested that the application of FACA to any advisory groups established and utilized by the President, because they advise someone in the Executive Office of the President, raises constitutional problems. We do not think we should entertain a constitutional argument of such enormous significance made in so glancing a fashion. After all, it could be thought to come close to an argument that the government disavowed-that FACA is unconstitutional on its face.

Id. at $912 \mathrm{n} .12$. The Justice Department pressed more strongly the arguments that the task force should be exempt because it did not meet face to face with the President and that, in considering constitutional difficulties, the main weight should be given to the infringement on the President's constitutional power to "recommend" legislation (which would have limited application of the constitutionally-forced exception to FACA to committees specifically concerned.with new legislation). 
considered a government official for purposes of FACA, would not also then have to be considered a government official in relation to conflict of interest standards. ${ }^{138}$ The White House Counsel's Office subsequently acknowledged that it had previously ruled that Mrs. Rodham Clinton was not subject to such standards and had not yet, at the time of the court of appeals ruling, transferred her personal financial holdings to a blind trust. ${ }^{139}$ There was the potential for still another constitutionally charged dispute in this claim that the First Lady, like the President and Vice-President, must be understood to be exempted from the conflict of interest laws. Yet none of the White House Counsel's rulings on the status of Mrs. Rodham Clinton-for all their potential constitutional implications-had been cleared with the OLC. ${ }^{140}$ The Counsel's Office seems to have felt confident that it could provide the President with adequate "advice"-even advice that would be invoked and relied upon in sensitive public controversies and ensuing litigation-without bothering to coordinate its position with the Justice Department.

The Clinton White House may have been irregular in this respect. The Administration was very slow in making appointments to the Justice Department and did not have its own appointees in place at OLC (or even in the Attorney General's Office) when initial positions had to be taken on the status of the First Lady. The apparent suicide of Associate Counsel Vincent Foster, who according to some reports was depressed at mistakes in the work of the Counsel's Office, may have had a chastening effect. But the episode illustrates the way in which the Counsel's Office, in its eagerness to smooth the way for preferred presidential policies, can launch the White House on a legal argument with very serious constitutional implications. Boyden Gray claims never to have taken a position on a major issue without consulting OLC and never to have advised the President in opposition to OLC's findings. ${ }^{141}$ No doubt, this is the norm. But the presence of the Counsel's Office is an invitation to the White House to take more convenient advice closer to home.

At every stage of the president's involvement with the development of constitutional law, then, the Counsel's Office may play an important role in the background. Even if its actions are unseen, the effects of the Counsel's activities may register in the ultimate results. The Counsel's advice or actions may not always be directed toward safeguarding presidential prerogatives. And advice or actions intended to strengthen the president's constitutional authority may fail in the courts or provoke more constraining, new legislation from Congress. But whatever the advice and action taken by the president-and often by his

138. Id. at $911 \mathrm{n} \cdot 10$ ("We do not need to consider whether Mrs. Clinton's presence on the Task Force violates ... any conflict of interest statute.").

139. Francis X. Clines, $A$ Fatal Silence and a Chance to Address It, N.Y. TIMEs, Aug. 22, 1993, at 33.

140. William Safire, On Foster's Mind, N.Y. TIMES, Aug. 16, 1993, at A17.

141. Interview with C. Boyden Gray (May 12, 1993); top aides to Gray confirm Gray's recollection on this point. 
appointees in executive departments-the legal calculations of the Counsel's Office in the White House will play an important role.

\section{VIII}

\section{CONClusion: What to MAKE OF THE COUNSEl?}

Since the White House Counsel's Office has no statutory basis, any president is free, at least in principle, to dispense with the entire office. Yet law is not the only constraint on presidential staffing choices. The political scientist Hugh Heclo put the point quite well more than a decade ago:

At first blush it would seem that the internal arrangements of his own office are simply a matter of presidential taste. And so they are in all unimportant respects .... In terms of deep structure, however, the office is largely a given that a president can change slowly if at all. This structure is the web of other people's expectations and needs. On the surface, the new president seems to inherit an empty house. In fact, he enters an office already shaped and crowded by other people's desires. ... What the winner [of the presidential election] grasps is an office that is the raw, exposed ganglion of government where immense lines of force come together in ways that no single person can control..$^{142}$

By now it is simply inconceivable that a president could dispense with the White House Counsel's Office or even pare it back to the single "special counsel" with one or two assistants with which presidents operated before 1970 . The president may not be commanded by law to maintain a Counsel's Office, but the law commands him to address a whole range of ethics and disclosure matters within the White House that require the continuing attention of a Counsel's Office. The President must operate with a political culture that constrains him from treating the top officials of the Justice Department as a compliant gang of cronies, solely attentive to his own concerns. And yet the president must still respond to pressures to address pressing constitutional issues of the day without appearing to engage in "partisan manipulation." The Counsel's Office, as it responds to deeply rooted needs at the White House, has a secure future in the president's inner court.

A dozen lawyers in the White House cannot substitute for the Department of Justice. They cannot compete with the resources of the Justice Department for careful and extensive legal research. They cannot even compete with the managerial resources of the Attorney General (or in practice, the Deputy Attorney General) for monitoring all of the potentially sensitive or important decisions that may arise in the course of routine business at the Justice Department or elsewhere in federal agencies and departments. And the limitations of the Counsel's Office go beyond the question of resources. Top officials of the Justice Department are constrained by Senate confirmation, 
formal oaths, long-established procedures and protocols, a career staff with professional norms and institutional memory-in short, with all the constraints of an institutionalized "office." The White House Counsel operates informally, usually in secret; it has no accountability to Congress and little institutional memory or assured continuity, since it maintains almost no permanent records and employs no ongoing, career staff.

In these circumstances, an enlarged Counsel's Office poses the same sorts of dangers that critics have decried in the large White House staffs of recent decades. ${ }^{143}$ There is always the danger that impulsive, inexperienced aides, puffed up with the prestige of the White House-and emboldened by the absence of personal accountability-will seek to bully the main federal establishments into reckless, ill-considered or improper actions in the service of pet ideological nostrums or short-term political aims. ${ }^{144}$ One incident of this kind was brought to light in the Clinton Administration and subsequently acknowledged by the White House itself as improper.

The matter arose from the decision of top Clinton aides to reorganize the White House travel office (which arranges transportation for journalists following the President) and put this technical service in the hands of a personal relation of President Clinton, who had financial ties to personal friends of the President. The White House officially insisted that the travel office had to be reorganized to correct serious abuses in the previous operation of the office. To lend weight to this story, lawyers in the Counsel's Office met with FBI agents-without the knowledge of the Director nor of the Attorney General-and directed the agents on how to report on their initial investigation of supposed financial improprieties in the administration of the travel office. Counsel Bernard Nussbaum subsequently apologized to the Attorney General, but insisted, in his own followup report on the episode, that no major wrong-doing had occurred in his office. $^{145}$

More serious abuses remain a perpetual danger, the more so as the influence of the Counsel's Office remains very difficult to detect from the outside. How far this danger materializes depends much on the character of the Counsel, and on the character of top officials in the departments, particularly the Justice

143. See, for example, National Academy of Public Administration, A Presidency for the 1980s, reprinted in THE ILLUSION OF PRESIDENTIAL GOVERNMENT 299-341 (Hugh Heclo \& Lester Salamon eds., 1981). "Recommendation 1" of this report is: "The trend toward enlargement of the White House staff should be reversed. Rigorous efforts should be made to keep this staff small." The explanation supplied for this recommendation is that "it is here [at the level of White House staff] that the temptation to speak on behalf of the President and to 'second-guess' the line agencies is especially strong; the larger the staff, the wider the circle of persons who may yield to this temptation, and the greater the chances of building an image, if not the reality, of White House aggrandizement." Id. at 318.

144. PATTERSON, supra note 21 , at 141 , offers this characteristic statement from an anonymous staff lawyer at OLC: "We certainly did not want some young, faceless twenty-five year old White House staffer taking issue with the Attorney General of the United States . . . and then taking the issue to the President in a memo which set forth two paragraphs and 'Mr. President, check the box below."

145. Editorial desk, A Stealthy, Evasive Confession, N.Y. TIMES, July 11, 1993, § 4, at 18; Myopia at the White House; The F.B.I., Abused, N.Y. TIMES, May 26, 1993, at A20. 
Department; it may depend, above all, on the character and attentiveness of the President and his relations with the Counsel, on the one hand, and the Attorney General and other Cabinet officers, on the other. The Clinton Administration may be particularly vulnerable to such dangers having installed a relatively obscure figure as Attorney General (a woman with no independent political weight and no close ties to the President) and then having left her to face a White House Counsel who is a far more experienced Washington hand and who has far closer and more long-standing ties to the President and the First Lady. ${ }^{146}$

In spite of these dangers, it is unrealistic to expect the president, personally, to attend to all the issues that enter the developmental stream of constitutional law. If the president does not have a legal staff to assist him, he will have to rely on the Justice Department. And in an era when constitutional law raises so many competing expectations and concerns of such great political moment, the Justice Department can hardly be expected to reach sound and acceptable decisions on its own on all issues. If it is not influenced by the president, the Justice Department is still likely to be influenced in many cases by the clamor of interest groups, by the threats and signals of congressional committees and congressional staff, and by the ideological and professional biases of lawyers within the Department, itself. Presidents may still feel compelled to intervene in the final decisions on Justice Department briefs before the Supreme Court, for example. But it is far better to exert ongoing influence over the development of "constitutional policy" from earlier stages, than to attempt a clumsy order at the last minute.

Similarly, when the president deliberates on his own constitutional power to act in a crisis or in a matter of controversy, he would be very foolish to ignore the advice of the Justice Department, with its accumulated legal learning, its research resources, and its long experience in defending presidential prerogatives. The president's understanding of his legal options, however, may be enhanced by access to legal advice that is not filtered through the institutional biases or political preoccupations of the Justice Department. It is just this sort of "second opinion" that the Counsel's Office can provide.

146. For early indications of grounds for concern on this score, see David Johnston, Reno's in Office; Is She in Charge?, N.Y. TIMES, Mar. 22,1993, at A1, reporting that Attorney General Janet Reno "risks ceding chunks of the [Justice] Department to the White House and its legal counsel, Bernard W. Nussbaum" because most of the top positions at Justice were chosen directly by the White House rather than by Reno, herself. The Wall Street Journal subsequently reported the experience of journalists who inquired about why the President's Task Force on Health Care Reform was organizing a public meeting in apparent violation of the Federal Advisory Committee Act and of a court order on March 10 to abide by its terms: when they sought legal rationales for this at the Department of Justice, the official Justice spokesperson told them to "call the White House." Editorial desk, The Wizards of Oz, WALL ST. J., Mar. 29, 1993, at A12. Earlier, Janet Reno ordered the removal of all incumbent U.S. Attorneys before any successors for them had been secured-an entirely unprecedented step, putting partisan loyalty above all considerations of continuity. She explained that the decision was a "joint decision with the White House," an explanation widely interpreted to mean that the White House had simply ordered the Attorney General to do so. 
Responding to calls for a reduced White House staff, political scientist Samuel Kernall noted that the large staff is the symptom and not the cause of White House needs to intervene more actively in departmental affairs:

To assume that the governability of the modern presidency simply required reducing the staff and returning it to its original size and import would be to ignore the pervasive environmental forces that have transformed presidential leadership. To try to remove surgically the problems that attend large organizations would only succeed in leaving the president an invalid, as selfreliant as ever, yet incapacitated. ${ }^{147}$

If the president wants to play a role in his own administration, he will need to have staff resources. If he wants to play an effective role in the evolution of constitutional law, he will need to have a sizable and capable White House Counsel's Office.

147. Samuel Kernall, The Evolution of the White House Staff, in CAN THE GOVERNMENT GOVERN? 185-237, 235 (John Chubb \& Paul Peterson eds., 1989). 